Canadian Journal of Fisheries and Aquatic Sciences Journal canadien des sciences halieutiques et aquatiques

\title{
Incorporation of Carbon and Nitrogen Isotopes in Age-0 Walleye (Sander vitreus) Tissues Following a Laboratory Diet Switch Experiment
}

\begin{tabular}{|c|c|}
\hline Journal: & Canadian Journal of Fisheries and Aquatic Sciences \\
\hline Manuscript ID & cjfas-2017-0301.R2 \\
\hline Manuscript Type: & Rapid Communication \\
\hline Date Submitted by the Author: & 18-Dec-2017 \\
\hline Complete List of Authors: & $\begin{array}{l}\text { Schumann, David; South Dakota State University, Natural Resource } \\
\text { Management } \\
\text { Uphoff, Christopher; University of Nebraska Kearney, Biology; Minnesota } \\
\text { Department of Natural Resources } \\
\text { Schoenebeck, Casey; University of Nebraska Kearney, Biology; Minnesota } \\
\text { Department of Natural Resources } \\
\text { Bertrand Graeb, Katie; South Dakota State University, Natural Resource } \\
\text { Management }\end{array}$ \\
\hline $\begin{array}{r}\text { Is the invited manuscript for } \\
\text { consideration in a Special } \\
\text { Issue? : }\end{array}$ & N/A \\
\hline Keyword: & $\begin{array}{l}\text { ISOTOPES < General, TROPHIC RELATIONSHIPS < General, DIET < } \\
\text { General }\end{array}$ \\
\hline
\end{tabular}

\section{SCHOLARONE ${ }^{m}$ \\ Manuscripts}


2 Incorporation of Carbon and Nitrogen Isotopes in Age-0 Walleye (Sander vitreus) Tissues

3 Following a Laboratory Diet Switch Experiment

4

5 David A. Schumann ${ }^{1,4}$, Christopher S. Uphoff ${ }^{2,3}$, Casey W. Schoenebeck ${ }^{2,3 *}$, and Katie N. B.

6 Graeb $^{1}$

$7 \quad{ }^{1}$ Department of Natural Resource Management, South Dakota State University, Box 2140B, SNP

8 138, Brookings, South Dakota 57007, USA

$9{ }^{2}$ Department of Biology, University of Nebraska at Kearney, $240111^{\text {th }}$ Avenue, Kearney,

10 Nebraska 68847, USA

$11{ }^{3}$ Minnesota Department of Natural Resources, 23070 North Lakeshore Drive, Glenwood,

12 Minnesota 56334, USA

$13{ }^{4}$ Department of Wildlife, Fisheries, and Aquaculture, Mississippi State University, Box 9690,

14 Mississippi State, Mississippi 39759, USA

15

16 *Author to whom correspondence should be addressed: Casey Schoenebeck; Telephone: 320-

17 634-7322; Email: Casey.Schoenebeck@state.mn.us

18 


\section{Abstract}

Trophic dynamics are often described by following the exchange of naturally occurring

21 isotopes through aquatic communities. However, without experimentally derived isotopic

22 turnover rates and discrimination factors for each species, tissue, and life stage, these trophic

23 models can be misleading. We conducted a laboratory diet-shift experiment to describe isotopic

24 turnover and discrimination in age-0 walleye (Sander vitreus) dorsal muscle and gutted carcass

25 samples. Although turnover of dietary $\delta^{13} \mathrm{C}$ (half-life: $10-12$ days) and $\delta^{15} \mathrm{~N}$ (half-life: $\sim 13$

26 days) signatures was relatively rapid, the diet change was undetected in both tissues during a

27 short transitional period (up to 1.2 times shorter in muscle). Our discrimination estimates

28 generally conform to those of other fishes $\left(\Delta_{\text {Carbon }}=0.91, \Delta_{\text {Nitrogen }}=1.6\right)$, but were $30-50 \%$ higher

29 in muscle tissues than gutted carcass samples. The assumption that young walleye tissues are in

30 equilibrium with their diet is untrue for weeks following a diet shift and, when incorporated,

31 discrimination factors differ between tissues. We provide tissue-specific parameters that remove

32 uncertainty associated with the analysis of field collected isotopic age- 0 walleye data. 


\section{Introduction}

Stable isotope analyses (SIA) track the exchange of naturally occurring isotopes in

animal tissues and, using consumer-resource ratios and assumed discrimination factors, infer energy sources and trophic relationships (DeNiro and Epstein 1978, 1981; Post 2002; McIntyre and Flecker 2006). Isotope signatures act as dietary tracers of assimilated organic matter and provide quantitative measures of trophic interactions among food-web components through space and time (DeNiro and Epstein 1978, 1981; Vander Zanden et al. 2015; Franssen et al. 2017). Although other elements have been applied to isotope studies, carbon $\left(\delta^{13} \mathrm{C}\right)$ and nitrogen $\left(\delta^{15} \mathrm{~N}\right)$ are the most commonly used in aquatic systems (DeNiro and Epstein 1978, 1981; Fry and Arnold 1982; Post 2002; Layman et al. 2012; Vander Zanden et al. 2015; Franssen et al. 2017).

Following a diet change, the isotopic compositions of new resources are assimilated into animal tissues over some uncertain period of time via metabolic pathways and somatic growth (Boecklen et al. 2011; Vander Zanden et al. 2015). Inferences from isotopic data assume that, when sampled, consumer tissues have reached isotopic equilibrium with their diet (Pinnegar and Polunin 1999; Post 2002; Vander Zanden et al. 2015). Fishes opportunistically feed on abundant prey, alter food sources during movements, and undergo multiple ontogenetic diet shifts (Ross 2013). If individuals retain isotopic signatures of previous prey items for long periods before new diets are assimilated, the equilibrium assumption can be violated (Herzka and Holt 2000; MacAvoy et al. 2001; Gaye-Siessegger et al. 2004; Vander Zanden et al. 2015; Franssen et al. 2017).

A large number of laboratory isotopic diet shift experiments have estimated trophic halflives for diverse taxa and tissues (see Boecklen et al. 2011; Vander Zanden et al. 2015). Although these rates are still unknown for most fishes and tissues, research shows that isotopic 
57 half-lives have varied widely among elements, species, tissues, and life-stages (MacAvoy et al.

58 2001; Gaye-Siesseggar et al. 2004; Jardine et al. 2005; Logan et al. 2006; McIntyre and Flecker

59 2006; Boecklen et al. 2011). The variability in isotopic half-lives has hindered the development

60 of robust predictive models for all fish species and tissue type combinations (Post 2002;

61 Boecklen et al. 2011; Vander Zanden et al. 2015). However, a recent review suggests that fish

62 size strongly influences the rate of isotopic turnover, which occurs more quickly in small

63 individuals (Hesslein et al. 1993; Buchheister and Latour 2010; Vander Zanden et al. 2015). In

64 the absence of experimentally derived isotopic turnover rates and discrimination factors, widely

65 applied trophic models are potentially misleading (Post 2002; Martinez del Rio et al. 2009;

66 Boecklen et al. 2011; Bond and Diamond 2011).

67 Although SIA offers unique insight into fish trophic ecology and can benefit fisheries management, including adult walleye (Sander vitreus), the technique is fraught with concerns

69 when applied to novel species, tissues, and life-stages (Overman and Parrish 2001; Boecklen et al. 2011; Fincel et al. 2014, 2015). Herein, we provide the first estimates of nitrogen and carbon

71 isotopic turnover rates and discrimination factors in two age- 0 walleye tissues. Walleye typically

72 undergo a series of ontogenetic diet shifts in the first growing season, initially consuming

73 zooplankton, then macroinvertebrates, and finally, fish (Mathias and Li 1982; Johnson and

74 Mathias 1994; Chipps and Graeb 2011). Walleye feeding habits (Fox 1989; Overman and Parrish

75 2001; Chipps and Graeb 2011; Bethke et al. 2012; Fincel et al. 2015) and population dynamics

76 (Sogard 1997; Uphoff et al. 2013) are largely influenced by prey size and availability during

77 their first growing season. Precise understanding of the dynamics of isotopic turnover and

78 discrimination may allow managers to ascertain the conditions in which walleye growth and

79 survival are maximized during the critical, first growing season. 
We used a laboratory diet switch that mimics the ontogenetic dietary transitions of young

81 walleye during their first growing season to estimate isotopic discrimination and turnover (Graeb

82 et al. 2005). Although most studies use dorsal white muscle for isotopic analyses in fishes

83 (Vander Zanden and Rasmussen 2001; Boecklen et al. 2011), obtaining enough tissue can be

84 problematic for small individuals (Minagawa and Wada 1984; Pinnegar and Polunin 1999).

85 Isotopic relationships between muscle and gutted carcass samples were compared to assess tissue-specific variability. The specific objectives of this study were to $(i)$ empirically estimate

87 the turnover rates and discrimination factors of nitrogen and carbon in dorsal muscle and gutted

88 carcass samples using the best available model; ( $i$ i) compare the dependence of isotope signatures on growth and metabolism in both tissues; and (iii) describe the relationship between stable isotope ratios of carbon and nitrogen sampled from dorsal muscle and gutted carcass samples. This isotopic analysis will contribute to better descriptions of walleye ontogeny and

92 may improve management outcomes for ecologically and economically valuable fisheries (Post and Evans 1989; Rice et al. 1993; Sogard 1997).

\section{Fish collection and husbandry}

The Calamus State Fish Hatchery in Nebraska provided age-0 walleye larvae for this

97 study (mean total length, $\mathrm{TL}=9.0 \mathrm{~mm}$; range $8.5-9.5 \mathrm{~mm}$ ). Hatchery staff spawned the walleye from eggs collected from wild broodstock. Walleyes were received by University of Nebraska at

99 Kearney wet laboratory prior to yolk sac absorption and were housed in $38 \mathrm{~L}$ aquaria at a density 100 of six individuals per liter. Following the onset of allochthonous feeding, larval walleyes were

101 fed brine shrimp (Artemia spp.) ad libitum for seven weeks to acclimate to laboratory conditions.

102 The acclimation period allowed the walleye to reach lengths representative of those in wild 
103 populations when shifting to piscivory (Chipps and Graeb 2011; Uphoff et al. 2013). We

104 assumed that parentally derived isotopic signatures were completely diluted (Vander Zanden et

105 al. 1998) and that isotopic equilibrium was reached with the brine shrimp before the diet switch.

106 The acclimation period approximates the half-lives of nitrogen (mean $=35.9$ days, standard

107 error, $\mathrm{SE}=7.1)$ and carbon $($ mean $=34.3$ days, $\mathrm{SE}=6.8)$ isotopes in similarly sized fish tissues

108 (Vander Zanden et al. 2015). We maintained a $13 \mathrm{~h}$ light - $11 \mathrm{~h}$ dark photoperiod and tank

temperatures at $20^{\circ} \mathrm{C}$; conditions typical of Nebraska reservoirs during walleye development

110 (Uphoff et al. 2013).

Prior to the start of the diet-shift experiment on 13 July 2011, we separated 77 juvenile

112 walleye (mean $\mathrm{TL}=54.8 \mathrm{~mm}, \mathrm{SE}=0.25$; range $=54-55 \mathrm{~mm}$ ) into a $194 \mathrm{~L}$ recirculating chamber

113 filled with dehlorinated municipal water. We sacrificed four walleyes from the experimental

114 group prior to the start of the experiment (12 July 2011) to measure the tissue isotopic signatures

115 before the diet switch. The remaining individuals $(n=73)$ were fed a diet of commercial dry fish

116 feed, hereafter referred to as "artificial feed" (Otohime C2: 840-1410 $\mu \mathrm{m}$; composition: $>20 \%$

117 fish meal, $>35 \%$ krill, $>15 \%$ squid meal; Reed Mariculture, Inc.). Fish were fed approximately

$1184.4 \%$ of their body weight daily and uneaten food was removed after fish stopped feeding to

119 maintain water quality.

120 The artificial feed emulated the ontogenetic diet shifts of walleye during their first

121 growing season (Table 1). Stable isotope ratios of nitrogen $\left({ }^{15} \mathrm{~N} /{ }^{14} \mathrm{~N}\right)$ and carbon $\left({ }^{14} \mathrm{C} /{ }^{13} \mathrm{C}\right)$ were

122 measured from the brine shrimp $(n=5)$ twice and the artificial feed $(n=10)$ once to ensure

123 consistency in the dietary isotopic signature. Brine shrimp isotopic signatures were measured at

124 the beginning of the seven-week acclimation period and four days prior to the diet switch. The

125 artificial diet isotopic signatures were assumed constant because a single package was used 
126 during the experiment. We pooled individual brine shrimp and feed granules and measured a

127 single sample of $3 \mathrm{mg}$ dry weight, DW for each diet.

We randomly euthanized and sampled tissues from 6-10 individuals each week for five

129 weeks to monitor the carbon and nitrogen isotope signatures in both tissues (University of

130 Nebraska at Kearney Institutional Animal Care and Use Committee \#042811). We sampled fish

131 on day 1 ( $n=6 ; 13$ July 2011) and again on experiment days $8,15,22,29$, and 36 (Figure 1$)$. We

132 weighed $(\mathrm{g})$ and measured each sacrificed fish to TL $(\mathrm{mm})$. We withheld food for $12 \mathrm{~h}$ prior to

133 sacrifice to allow for gut evacuation. In the laboratory, we excised samples of the dorsal muscle

134 from above the pectoral fin and anterior to the dorsal fin for each sample. We rinsed the dorsal

135 muscle sample and the remaining gutted carcass with deionized water, and dried each at $75^{\circ} \mathrm{C}$ for

$13648 \mathrm{~h}$. Because tissues within the body cavity turnover at different rates (Jardine et al. 2005), all

137 visceral organs were removed from the composite gutted carcass sample. Tissue samples were

138 ground with mortar and pestle, and packaged into a $4 \mathrm{~mm} \times 6 \mathrm{~mm}$ tin capsule before being

139 placed in glass scintillation vials awaiting further analysis.

\section{Sample processing}

Prepared tissue samples were analyzed for carbon and nitrogen stable isotopes at the

142 Cornell University Stable Isotope Laboratory (Ithaca, New York) using a Finnigan MAT Delta

143 Plus isotope ratio mass spectrometer. Stable isotope ratios were expressed in delta $(\delta)$, in parts

144 per thousand (\%), in relation to conventional standards:

145

$$
\text { (1) } \delta X=\frac{\left(R_{\text {sample }}-R_{\text {standard }}\right)}{R_{\text {standard }}} \times 1000
$$

146 where $X$ is the stable isotope of carbon or nitrogen and $R$ is the mass ratio of the heavy to light

147 stable isotopes (e.g., $\left.{ }^{15} \mathrm{~N} /{ }^{14} \mathrm{~N}\right)$ for both the sample and standard. Standards were Pee Dee 
148 Belemnite for carbon and atmospheric nitrogen. Repeated measurements of a calibration

149 standard at 10 sample increments indicated that instrument precision was $0.08 \%$ and $0.25 \%$ for

$150 \delta^{13} \mathrm{C}$ and $\delta^{15} \mathrm{~N}$, respectively. Ratios of carbon to nitrogen $(\mathrm{C}: \mathrm{N})$ were calculated from measured

151 amounts in each sample and ranged between $3.2-5.2($ mean $=3.7, \mathrm{SE}=0.05)$. We corrected

$152 \delta^{13} \mathrm{C}$ values mathematically to reduce lipid bias (Post et al. 2007; Logan et al. 2008):

153

(2) $\delta^{13} \mathrm{C}_{\text {corrected }}=\left(\delta^{13} \mathrm{C}-3.32+0.99\right) \times \mathrm{C}: \mathrm{N}$

154

155

156

157

158

159

160

161

162

163

164

165

166

167

168

169

\section{Isotopic turnover and discrimination}

Several distinct model structures can be used to estimate isotopic turnover and discrimination in consumer tissues following a diet change (Boecklen et al. 2011; Vander Zanden et al 2015). The different modeling frameworks express isotopic turnover as a function of either weight change or time (Vander Zanden et al. 2015). Because fish growth and metabolic processes can affect isotopic signatures, we used growth- and time-based models to assess isotopic change in age- 0 walleye tissues and compared their relative fits.

\section{Growth-based model}

We fit a growth-based model (Fry and Arnold 1982) to walleye isotopic values to quantify the relationship between growth rates and isotopic turnover after consuming an enriched, artificial diet (Buchheister and Latour 2010; Franssen et al. 2017). This model predicts the isotopic signature of consumer tissues given its relative increase in weight as:

(3) $\delta_{\mathrm{WR}}=\delta_{\mathrm{f}}+\left(\delta_{\mathrm{i}}-\delta_{\mathrm{f}}\right) \mathrm{W}_{\mathrm{R}}^{\mathrm{c}}$

where $\delta_{\mathrm{WR}}$ is the predicted isotopic signature of a fish tissue, $\delta_{\mathrm{f}}$ is the expected isotopic signature at equilibrium, and $\delta_{\mathrm{i}}$ is the initial isotopic value prior to the diet shift. We used the mean isotope signature from the four individuals sacrificed prior to the diet shift for $\delta_{\mathrm{i}}$. The relative increase in 
170 wet weight $\left(\mathrm{W}_{\mathrm{R}}\right)$ was calculated as the walleye wet weight when sampled divided by the mean

171 initial wet weight (mean $=1.10 \mathrm{~g}, \mathrm{SE}=0.027)$ and $c$ is the curve-fitted turnover rate constant.

172 Values of $\mathrm{c}$ equal to -1 indicate that isotopic change is only a result of somatic growth, whereas

173 values of $\mathrm{c}<-1$ suggest that metabolic processes influence isotopic turnover rates. A $z$ test was

174 used to test the estimated parameter $c$ against the null hypothesis, $c=-1$ (Zar 2010).

175 We calculated the amount of change in wet weight needed to achieve $\alpha$ percent turnover of $176 \quad \delta^{13} \mathrm{C}$ and $\delta^{15} \mathrm{~N}\left(G_{\alpha / 100}\right)$ as:

177

(4) $G_{\alpha / 100}=\exp \left(\frac{\ln \left(1-\frac{\alpha}{100}\right)}{c}\right)$

178 The growth-based half-life $\left(G_{0.5}\right)$ was obtained when $\alpha=50 \%$ and represents the amount of 179 growth needed to observe $50 \%$ conversion in consumer tissues. We calculated the change to 180 sample tissues derived from growth $\left(D_{\mathrm{g}}\right)$ and from metabolic activity $\left(D_{\mathrm{m}}\right)$ using the half-life 181 (Buchheister and Latour 2010):

182

183

(5) $\quad D_{\mathrm{g}}=\frac{2\left(G_{0.5}-1\right)}{G_{0.5}}$

(6) $D_{\mathrm{m}}=\frac{\left(2-G_{0.5}\right)}{G_{0.5}}$

\section{Time-based models}

We also estimated changes in stable isotope ratios through time $(t)$ using a time-based 186 exponential model developed by Hesslein et al. (1993):

(7) $\delta_{\mathrm{t}}=\delta_{\mathrm{f}}+\left(\delta_{\mathrm{i}}-\delta_{\mathrm{f}}\right) \mathrm{e}^{-\left(k^{\prime}+m\right) t}$

where $m$ is a metabolic turnover constant. The growth rate constant, $k$, was derived from an exponential growth model of walleye growth: 
(8) $W_{\mathrm{f}}=W_{\mathrm{i}} \mathrm{e}^{k^{\prime} t}$

191 where $W_{i}$ is the initial wet weight and $\mathrm{W}_{\mathrm{f}}$ is the final weight when sampled on day $t$. In the time-

192 based model, if turnover is due to growth alone then $m$ will equal 0 . The values of $\delta_{\mathrm{t}}, \delta_{\mathrm{i}}$, and $t$

193 were measured or calculated, whereas $\delta_{\mathrm{f}}, m$, and $k^{\prime}$ parameter were estimated using nonlinear

194 regression.

195 We estimated the length of time needed to achieve $\alpha$ percent turnover of $\delta^{13} \mathrm{C}$ or $\delta^{15} \mathrm{~N}$ as

196 (Buchheister and Latour 2010):

197

(9) $\quad\left(T_{\alpha / 100}\right)=\left(\frac{\ln \left(1-\frac{\alpha}{100}\right)}{-\left(k^{\prime}+m\right)}\right)$

198 We calculated the isotope half-life $\left(T_{0.5}\right)$ at $\alpha=50 \%$.

199 We estimated the relative contributions of growth $\left(k^{\prime}=0.048\right)$ and metabolism $(m)$ as the

200 ratio of each parameter to the sum of the two parameters. This calculation yielded the proportion

201 of turnover attributable to growth $\left(P_{\mathrm{g}}\right)$ and metabolism $\left(P_{\mathrm{m}}\right)$. A $z$ test was used to test $m$ against

202 the null hypothesis that $m=0$ (Zar 2010).

\section{Discrimination}

204 Discrimination factors for each isotope and tissue combination were calculated as the

205 difference between the mean isotopic signature of the diet and the predicted isotopic equilibrium.

206 Discrimination of $\delta^{13} \mathrm{C}$ and $\delta^{15} \mathrm{~N}$ between the artificial diet and both dorsal muscle and the gutted

207 carcass sample $\left(\Delta_{\text {Tissue }}\right)$ were calculated following Minagawa and Wada (1984); Buchheister and

208 Latour (2010):

$209 \quad(10) \Delta_{\text {Tissue }}=\delta_{\mathrm{f}}-\delta_{\mathrm{d}}$ 
210 where $\delta_{\mathrm{d}}$ is the mean stable isotope signature for the samples of the artificial diet. Standard error

211 values associated with the fractionation estimate were based on errors related with the model

212 estimate of $\delta_{\mathrm{f}}\left(\mathrm{SE}_{\delta \mathrm{f}}\right)$ and the standard error of the mean for $\delta_{\mathrm{d}}\left(\mathrm{SE}_{\delta \mathrm{d}}\right)$ :

213

(11) $\mathrm{SE}_{\Delta \mathrm{Tissue}}=\sqrt{\mathrm{SE}_{\delta_{\mathrm{f}}}^{2}+\mathrm{SE}_{\delta_{\mathrm{d}}}^{2}}$

\section{Model selection}

An information-theoretic model selection approach was used to assess relative support

216 for four candidate models: model A, growth-based with a metabolic contribution to turnover;

217 model B, growth-based with no metabolic contribution to turnover (i.e., $c=-1$ ); model C, time-

218 based with a metabolic contribution to turnover; and model D, time-based with no metabolic

219 contribution to turnover (i.e., $m=0$ ). We compared model fit using Akaike's information

220 criterion corrected for small sample sizes ( $\mathrm{AIC}_{\mathrm{c}}$; Burnham and Anderson 2002).

221 Relationship of dorsal muscle signature to gutted carcass signature

222

Linear regression analysis was used to describe the relationships between tissue types for

223 each isotope. Regression parameters (slope, intercept) were used to develop a predictive model

224 for estimating dorsal muscle isotope values from gutted carcass values. All statistical analyses

225 and parameter estimates were conducted in SAS version 9.3 (SAS Institute Inc., Cary, North

226 Carolina, USA).

227

\section{Results}

Thirteen fish (18\%) died during the study; however, the remaining individuals $(n=60)$ were sufficient to sample stable isotope signatures throughout the study's duration. Walleye mean TL nearly doubled (final TL $=92.9 \mathrm{~mm}, \mathrm{SE}=1.80$ ) and mean wet weight increased by more than five times during the experimental period (Figure 1). Estimated growth rates of 
232 experimental walleye (specific growth rate, SGR; range: $2.8-6.6 \%$ day $^{-1}$ ) mirrored wild age-0 233 growth rates in Nebraska reservoirs (SGR: 6.1\% day ${ }^{-1}$; C. Uphoff, unpublished data). Initial $\delta^{15} \mathrm{~N}$ and $\delta^{13} \mathrm{C}$ isotopic signatures were similar between tissue types and both 235 tissues were different than the artificial diet $\left(\delta^{15} \mathrm{~N}: F_{2,15}=5321.42, p<0.01 ; \delta^{13} \mathrm{C}: F_{2,15}=\right.$ 236 1712.90, $p<0.01$; Table 1). The isotopic signatures of the artificial diet and brine shrimp were 237 significantly different $\left(\delta^{15} \mathrm{~N}: F_{1,18}=3438.66, p<0.01 ; \delta^{13} \mathrm{C}: F_{1,18}=2796.99, p<0.01\right.$; Table 1). 238 After the diet shift, isotopic turnover of walleye tissues was evident for both $\delta^{15} \mathrm{~N}$ and $\delta^{13} \mathrm{C}$ 239 (Figure 2). Time-based models were consistently supported by $\delta^{13} \mathrm{C}$ and $\delta^{15} \mathrm{~N}$ assimilation data 240 measured in muscle and gutted carcass samples (Table 2). The time-based model, parameterized

241 to exclude the influence of metabolism ( $m=0$; model D), performed better than the other 242 candidate models in all cases (Table 2). Model D was, on average, 6.2 times more likely to be the 243 best fitting model for our data than the next best model in the candidate set (range: 3.05 - 15.00;

244 Table 2). The comparatively large $\Delta \mathrm{AIC}_{\mathrm{c}}$ values of other competing models suggest that the 245 influence of metabolism on isotopic turnover of these tissues is weak during the rapid growth 246 period evaluated (Table 2). Based on the empirically best supported time-based model, rates of isotopic turnover 248 were equal between tissue types for $\delta^{15} \mathrm{~N}$ (Table 3; Figure 2). A larger $m$ value indicated that 249 turnover of $\delta^{13} \mathrm{C}$ occurred more quickly in gutted carcass samples than dorsal muscle tissues 250 (Table 3; Figure 2). Assimilation rates of the artificial diet were 1.01 times $\left(\delta^{15} \mathrm{~N}\right.$; time-based 251 model estimate) and 1.24 times $\left(\delta^{13} \mathrm{C}\right.$; time-based model estimate) faster in the gutted carcass 252 composite than in the dorsal muscle samples (Table 4). Half-lives for $\delta^{15} \mathrm{~N}$ in the dorsal muscle 253 and gutted carcass tissues were estimated as 13.0 and 13.2 days for age- 0 walleye, respectively 254 (Table 4). Further calculation found that a $95 \%$ isotopic turnover of $\delta^{15} \mathrm{~N}$ in age- 0 walleye tissue 
255 would require approximately 56 days for both tissue types evaluated (Table 4). The amount of

256 time necessary for a $50 \%$ conversion of $\delta^{13} \mathrm{C}$ in dorsal muscle and gutted carcass composite were

257 estimated as 12.1 and 9.7 days for age-0 walleye, respectively (Table 4). A 95\% isotopic

258 turnover of $\delta^{13} \mathrm{C}$ in age-0 walleye samples would require nearly 52.4 days for dorsal muscle and

25942.1 days for the gutted carcass composite (Table 4). Although not as well supported by the data, 260 growth-based parameter estimates (Table 3; Figure 2) and turnover half-lives are provided (Table 261 5). The half-life for $\delta^{15} \mathrm{~N}$ and $\delta^{13} \mathrm{C}$ for both tissues occurred after individuals reached weights 262 approximately 1.5 times their initial wet weight (Table 5). Metabolic contributions to $\delta^{13} \mathrm{C}$ turnover were apparent for gutted carcass samples when

264 estimated using the time-based model; however, there was no evident contribution of metabolism 265 to the turnover of $\delta^{15} \mathrm{~N}$ (Table 3). The time-based $\delta^{13} \mathrm{C}$ model indicated that metabolic activity 266 was important to isotopic turnover of gutted carcass composite tissues because the turnover 267 constant value $(m)$ was significantly different than zero $(z=3.85, P<0.001$; Table 3$)$. The time268 based model predicted that metabolic activity accounted for $32 \%$ of $\delta^{13} \mathrm{C}$ turnover and only $9 \%$ 269 of $\delta^{15} \mathrm{~N}$ turnover in the gutted carcass sample (Table 4). In growth-based models, metabolic 270 activity contributed significantly to the turnover of carbon in both dorsal muscle and gutted 271 carcass composite tissues (Table 3).

\section{Discrimination}

At the start of the study, walleye tissue $\delta^{15} \mathrm{~N}$ values were approximately $3 \%$ removed

274 from the brine shrimp diet and nearly $8 \%$ removed from the mean isotopic signature of the

275 artificial diet (Table 1). Initial values of $\delta^{13} \mathrm{C}$ were about 5\%o removed from the artificial diet in

276 both tissues (Table 1). Regardless of the model applied, estimates of $\delta^{15} \mathrm{~N}$ isotopic equilibrium

277 were dissimilar between tissues (Table 3). Discrimination estimates for $\delta^{15} \mathrm{~N}$ in the gutted 
278 carcass were approximately half of those from dorsal muscle samples (Table 3). The time-based

279 model predicted discrimination of $\delta^{15} \mathrm{~N}$ as $0.80 \pm 0.33$ in gutted carcass sample and $1.80 \pm 0.21$

280 in dorsal muscle tissue (Table 3). Estimates of $\delta^{13} \mathrm{C}$ isotopic equilibrium were more similar, but

281 were still about 30\% higher in dorsal muscle tissues than gutted carcass samples (Table 3).

282 Discrimination of $\delta^{13} \mathrm{C}$ was $0.94 \%$ for dorsal muscle to $0.69 \%$ or gutted carcass samples (Table 283 3).

284 Relationships of stable isotope signatures between tissues

285

All 60 Walleye $(\mathrm{TL}=49-101 \mathrm{~mm})$ yielded adequate amounts of both tissues for stable

286 isotope analysis and were used to compare dorsal muscle and gutted carcass composite isotopic

287 values (Figure 3). Both model structures predicted more rapid turnover of both elements in

288 gutted carcass samples than in dorsal muscle tissues (Figure 2). There was a significant

289 difference between dorsal muscle and gutted carcass composite isotope signatures for both $\delta^{15} \mathrm{~N}$

$290(F=145.91, P<0.001)$ and $\delta^{13} \mathrm{C}(F=76.9, P<0.001)$ when controlling for time. However, a

291 positive linear relationship was observed between tissue signatures for $\delta^{15} \mathrm{~N}$ (slope $=0.92$,

292 intercept $\left.=1.77, r^{2}=0.94\right)$ and $\delta^{13} \mathrm{C}\left(\right.$ slope $=0.79$, intercept $\left.=-3.97, r^{2}=0.85\right)$ isotopes (Figure

$2933)$.

\section{Discussion}

Common to fast-growing age-0 fishes, isotopic turnover occurred relatively quickly in walleye tissues during the diet shift and was only slightly influenced by metabolic processes.

297 Although discrimination factors generally conformed to those of other fishes, they varied by

298 tissue and element. We provide mathematical corrections to convert isotopic signatures between

299 tissues, when sampling is tissue prohibitive. Even though turnover was fairly rapid in both

300 walleye tissues, the transitional period during which consumer tissues do not fully reflect the diet 
301 being consumed should be considered when interpreting field collected isotopic data (Boecklen 302 et al. 2011; Vander Zanden et al. 2015).

For all isotope-tissue combinations, the time-based models were more supported by 304 available data than growth-based methods. Time-based models were also best supported in 305 similar research on turnover processes of other fish species (Bosley et al. 2002; Gaye-Siessegger 306 et al. 2004; Franssen et al. 2017). Variability in individual walleye growth rates had little 307 influence on parameter discrepancies, thereby supporting the use of a single population growth 308 parameter to estimate isotopic turnover dynamics. Although these experimental trials provided 309 considerable support for the time-based model parameter estimates, it may be important to 310 evaluate this relationship when considerable variation in growth rates are induced, such as with 311 alterations to temperature and feeding rates (Bosley et al. 2002; Gaye-Siessegger et al. 2004; 312 Vander Zanden et al. 2015).

Differences in turnover rates between the tissues were relatively small, but turnover 314 always occurred more quickly for $\delta^{13} \mathrm{C}$ than $\delta^{15} \mathrm{~N}$. Although analogous research has 315 demonstrated the same relationship in other fishes, the tissues evaluated have regularly had little 316 metabolic activity (e.g., Hesslein et al. 1993; Sweeting et al. 2005; McIntyre and Flecker 2006; 317 Boecklen et al. 2011). Isotopic turnover likely occurs faster in more metabolically active tissues 318 such as mucus, liver, and blood (Suzuki et al. 2005; Logan et al. 2006; MacNeil et al. 2006; 319 Church et al. 2009; Buchheister and Latour 2010; Chen et al. 2012). Including additional tissue 320 types, presumably with more rapid turnover, may aid in developing more complete dietary 321 histories and further our understanding of fish feeding ecology in early life stages (Overman and 322 Parrish 2001; Jardine et al. 2005). This technique has already proven advantageous for adult 323 walleye (Fincel et al. 2012). The rate in which new diets are integrated into fish tissues is 
324 particularly important when studying temporal trophic dynamics, which would remain 325 ambiguous without these tissue and element specific assimilation parameters (Herzka and Holt 326 2000; MacAvoy et al. 2001; Franssen et al. 2017). Similar to studies of other fast-growing ectothermic animals, somatic growth and to a lesser extent metabolic tissue replacement mediated isotopic turnover in young walleye tissues 329 (Fry and Arnold 1982; Hesslein et al. 1993; Buchheister and Latour 2010). Somatic growth has 330 controlled the rate of isotopic dilution in other species (Hesslein et al. 1993; Herzka and Holt 2000; MacAvoy et al. 2001; Bosley et al. 2002; Logan et al. 2006; Buchheister and Latour 2010; Vanden Zanden et al. 2015), and largely contributed to isotopic turnover of nitrogen in young walleye. As with other studies of isotopic turnover in fishes, metabolic processes contributed more to carbon assimilation, particularly for gutted carcass samples (Suzuki et al. 2005; Franssen et al. 2017). Several explanations exist to explain different isotopic responses between elements, 336 often citing metabolism and lipid concentrations (MacAvoy et al. 2001; Suzuki et al. 2005; 337 Buchheister and Latour 2010); however, ontogenetic changes to carbon isotopic signatures have 338 been recently recognized (Franssen et al. 2017). Our analysis provides additional evidence that 339 carbon isotope signatures undergo ontogenetic changes over time. Strong support for the time340 based models, larger metabolic contributions, and faster turnover of carbon suggest that 341 ontogeny may alter $\delta^{13} \mathrm{C}$ isotopic signatures (Franssen et al. 2017). Although somatic growth 342 strongly influences isotopic turnover in walleye tissues, isotopic changes to carbon signatures 343 seem to include additional physiological changes. tissues has been primarily studied for dorsal muscle tissues, but several more recent studies have 346 included additional tissues (Jardine et al. 2005; Church et al. 2009; Buchheister and Latour 2010; 
347 Chen et al. 2012). Patterns and variability in diet-tissue discrimination factors have been 348 summarized (Vander Zanden and Rasmussen 2001; Boecklen et al. 2011). Discrimination 349 estimates of $\delta^{15} \mathrm{~N}$ in young walleye tissues were within the range typically found in the literature $350(1 \%-6 \%$; McCutchan et al. 2003). However, our estimates of nitrogen discrimination were 351 consistently less than the long-standing intraspecific mean (3.4\%; Vander Zanden and 352 Rasmussen 2001; Post 2002). This is potentially related to the relatively high amount of 353 algivorous krill in the artificial diet. In contrast, our estimates of $\delta^{13} \mathrm{C}$ discrimination in walleye 354 tissues well conformed to the traditionally assumed values of 0\% - 1\%o (Post 2002; McCutchan 355 et al. 2003). Of particular concern to field isotopic studies, the discrimination values for carbon 356 and nitrogen differed between tissues. Variability in discrimination factors by tissue is likely a 357 result of diverse biochemical constituents within each tissue (e.g., amino acids, protein, lipids) 358 and allocation of resources during digestion (DeNiro and Epstein 1977, 1981; Post 2002; 359 McCutchan et al. 2003; Buchheister and Latour 2010). Divergent discrimination factors among 360 tissues could have a large influence on trophic inferences if not accounted for. High variability in isotopic half-lives and discrimination factors have prompted concern 362 about the reliability of trophic models without experimentally derived species and tissue specific 363 parameters (Post 2002; Martinez del Rio et al. 2009; Boecklen et al. 2011; Vander Zanden et al. 364 2015). Although generalized models may provide broad patterns, they may inappropriately 365 define diets and trophic positions of novel species, tissues, and life stages (Boecklen et al. 2011; 366 Vander Zanden et al. 2015). Many researchers sample white muscle because of its low lipid 367 concentration and ease of homogenization (Boecklen et al. 2011). But, because sufficient dorsal 368 muscle tissue is often difficult to obtain from small-bodied fishes or larval walleye, our 
369 correction factor allows the estimation of dorsal muscle signatures from gutted carcass composite

370 samples for both isotopes evaluated.

371 Although the turnover of nitrogen and carbon isotopes in age- 0 walleye tissues was

372 generally rapid, a transitional period exists in which tissues do not fully reflect the diet being

373 consumed. The assumption that young walleye tissues are in equilibrium with their diet may be

374 untrue for weeks following a diet shift. Sizeable error could be incorporated into dietary analyses

375 using stable isotopes if isotopic turnover rates and tissue-specific discrimination factors are not

376 considered. These experimentally derived, species and tissue specific turnover rates and

377 discrimination factors will remove uncertainty currently associated with the analysis of field

378 collected isotopic age- 0 walleye data.

\section{Acknowledgements}

We thank the University of Nebraska at Kearney, Joshua Kreitman and multiple graduate

381 students and laboratory technicians for lab assistance. This project was funded by the Research

382 Services Council at the University of Nebraska at Kearney. C. Uphoff and C. Schoenebeck were

383 also supported by Federal Aid in Sport Fish Restoration funds (Federal Aid Project F-160-R-8)

384 administered by the Nebraska Game and Parks Commission. Critical comments on our work and 385 suggestions for improvement were made by Michael Brown and two anonymous reviewers. 


\section{Literature Cited}

388

389

390

391

392

393

394

395

396

397

398

399

400

401

402

403

404

405

406

407

408

409

410

Bethke, B.J., Vandehey, J.A., Fincel, M.J., Graeb, B.D.S., and Porath, M.T. 2012. Walleye trophic position before and after a gizzard shad extirpation. Prairie Nat. 44: 72-78.

Bond, A.L., and Diamond, A.W. 2011. Recent Bayesian stable-isotope mixing models are highly sensitive to variation in discrimination factors. Ecol. Appl. 21: 1017-1023.

Bosley, K.L., Witting, D.A., Chambers, R.C., and Wainright, S.C. 2002. Estimating turnover rates of carbon and nitrogen in recently metamorphosed winter flounder (Pseudopleuronectes americanus) with stable isotopes. Mar. Ecol. Prog. Ser. 236: 233240.

Buchheister, A., and Latour, R.J. 2010. Turnover and fractionation of carbon and nitrogen stable isotopes in tissues of a migratory coastal predator, summer flounder (Paralichthys dentatus). Can. J. Fish. Aquat. Sci. 67: 445-461.

Burnham, K.P., and Anderson, D.R. 2002. Model selection and multimodel inference: a practical information theoretic approach, $2^{\text {nd }}$ edition. Springer Science, New York.

Chipps, S.R., and Graeb, B.D.S. 2011. Feeding ecology and energetics. In Biology, management, and culture of walleye and sauger. Edited by B.A. Barton. American Fisheries Society, Bethesda, Maryland. pp. 303-320.

Church, M. R., Ebersole, J.L., Rensmeyer, K.M., Couture, R.B., Barrowsa, F.T., and Noakes, D.L.G. 2009. Mucus: a new tissue fraction for rapid determination of fish diet switching using stable isotope analysis. Can. J. Fish. Aquat. Sci. 66: 1-5.

DeNiro, M.J., and Epstein, S. 1978. Influence of diet on the distribution of carbon isotopes in animals. Geochim. Cosmochim. Acta, 42: 495-506.

DeNiro, M.J., and Epstein, S. 1981. Influence of diet on the distribution of nitrogen isotopes in animals. Geochim. Cosmochim. Acta, 45: 341-351. 
411 Fincel, M.J., VanDeHey, J.A., and Chipps, S.R. 2012. Nonlethal sampling of walleye for stable isotope analysis: a comparison of three tissues. Fish. Manag. Ecol. 19: 283-292.

Fincel, M.J., James, D.A., Chipps, S.R., and Davis, B.A. 2014. Using cumulative diet data and stable isotope analysis to determine trophic position of walleye in a large, complex system. J. Fresh. Ecol. 29: 441-447.

Fincel, M.J., Chipps, S.R., Graeb, B.D.S., and Brown, M.L. 2015. Diet Breadth and variability in Sander spp. inferred from stable isotopes. River Res. Appl. 32: 984-991.

Fox, M.G. 1989. Effect of prey density and prey size on growth and survival of juvenile walleye (Stizostedion vitreum vitreum). Can. J. Fish. Aquat. Sci. 46: 1323-1328.

Franssen, N.R., Gilbert, E.I., James, A.P., and Davis, J.E. 2017. Isotopic tissue turnover and discrimination factors following laboratory diet switch in Colorado pikeminnow (Ptychocheilus lucius). Can. J. Fish. Aquat. Sci. 74: 265-272.

Fry, B., and Arnold, C. 1982. Rapid ${ }^{13} \mathrm{C} /{ }^{12} \mathrm{C}$ turnover during growth of brown shrimp (Penaceus aztecus). Oecologia, 54: 200-204.

Gaye-Siessegger, J., Focken, U., Muetzel, S., Abel, H.J., and Becker, K. 2004. Feeding level and individual metabolic rate affect $\delta^{13} \mathrm{C}$ and $\delta^{15} \mathrm{~N}$ values in carp: implications for food web studies. Oecologia, 138: 175-183.

Graeb, B.D.S., Galarowicz, T., Wahl, D.H., Dettmers, J.M., and Simpson, M.J. 2005. Foraging behavior, morphology, and life history variation determine the ontogeny of piscivory in two closely related predators. Can. J. Fish. Aquat. Sci. 62: 2010-2020.

Herzka, S.Z., and Holt, G.J. 2000. Changes in isotopic composition of red drum (Sciaenops ocellatus) larvae in response to dietary shifts: potential applications to settlement studies. Can. J. Fish. Aquat. Sci. 57: 137-147. 
434 Hesslein, R.H., Hallard, K.A., and Ramlal P. 1993. Replacement of sulfur, carbon, and nitrogen 435 in tissue of growing broad whitefish (Coregonus nasus) in response to a change in diet

Jardine, T.D, Gray, M.A., McWilliam, S.M, and Cunjack, R.A. 2005. Stable isotope variability traced by $\delta^{34} \mathrm{~S}, \delta^{13} \mathrm{C}$, and $\delta^{15}$ N. Can. J. Fish. Aquat. Sci. 50: 2071-2076.

Johnson, T.A., and Mathias, J.A. 1994. Feeding ecology of walleye, Stizostedion vitreum, larvae: effects of body size, zooplankton abundance and zooplankton community composition. Ca. J. Fish. Aquat. Sci. 51: 2077-2089.

442

443

$$
\text { in tissues of temperate stream fishes. Tans. Am. Fish. Soc. 134(5): 1103-1110. }
$$

Ca. J. Fish. Aquat. Sci. 51: 2077-2089.

Layman, C.A., Araujo, M.S., Boucek, R., Harrison, E., Jud, Z.R., Matich, P., HammerschlagPeyer, C.M., Rosenblatt, A.E., Vaudo, J.J., Yeager, L.A., Post, D., and Bearhop, S. 2012. Applying stable isotopes to examine food-web structure: an overview of analytical tools. Biol. Rev. 87: 545-562.

Logan, J., Haas, H., Deegan, L., and Gaines, E. 2006. Turnover rates of nitrogen stable isotopes in the salt marsh mummichog, Fundulus heteroclitus, following a laboratory diet switch. Oecologia, 147: 391-395.

Logan, J.M., Jardine, T.D., Miller, T.J., Bunn, S.E., Cunjack, R.A., and Lutcavage, M.E. 2008. Lipid corrections in carbon and nitrogen stable isotope analyses: comparison of chemical extraction and modelling methods. J. Anim. Ecol. 77:838-846.

MacAvoy, S.E., Macko, S.A., and Garman, G.C. 2001. Isotopic turnover in aquatic predators: quantifying the exploitation of migratory prey. Can. J. Fish. Aquat. Sci. 58: 923-932.

MacNeil, M.A., Drouillard, K.G., and Fisk, A.T. 2006. Variable uptake and elimination of stable nitrogen isotopes between tissues in fish. Can. J. Fish. Aquat. Sci. 63: 345-353. 
Martinez del Rio, C., Wolf, N., Carleton, S.A., and Gannes, L.Z. 2009. Isotopic ecology ten years after a call for more laboratory experiments. Biol. Rev. 84: 91-111.

Mathias, J.A., and Li, S. 1982. Feeding habits of walleye larvae and juveniles: comparative laboratory and field studies. Tans. Am. Fish. Soc. 111: 722-735.

McIntyre, P.B., and Flecker, A.S. 2006. Rapid turnover of tissue nitrogen of primary consumers in tropical freshwaters. Oecologia, 148: 12-21.

Minagawa, M., and Wada, E. 1984. Stepwise enrichment of ${ }^{15} \mathrm{~N}$ along food chains: further evidence and the relation between ${ }^{15} \mathrm{~N}$ and animal age. Geochimica et Cosmochimica Acta 48: 1135-1140.

Overman, N.C., and Parrish, D.L. 2001. Stable isotope composition of walleye: ${ }^{15} \mathrm{~N}$ accumulation with age and area-specific differences in $\delta^{13} \mathrm{C}$. Can. J. Fish. Aquat. Sci. 58: $1253-1260$.

Pinnegar, J.K., and Polunin, V.C. 1999. Differential fractionation of $\delta^{13} \mathrm{C}$ and $\delta^{15} \mathrm{~N}$ among fish tissues: implications for the study of trophic interactions. Funct. Ecol. 13: 225-231.

Post, J.R., and Evans, D.O. 1989. Size-dependent overwinter mortality of young-of-the-year yellow perch (Perca flavescens): laboratory, in situ enclosure, and field experiments. Can. J. Fish. Aquat. Sci. 46: 1958-1968.

Post, D.M. 2002. Using stable isotopes to estimate trophic position: models, methods, and assumptions. Ecology, 83: 703-718.

Rice, J.A., Miller, T.J., Rose, K.A., Crowder, L.B., Marschall, E.A., Trebitz, A.S., and DeAngelis, D.L. 1993. Growth-rate variation and larval survival: inferences from an individual-based size-dependent predation model. Can. J. Fish. Aquat. Sci. 50: 133-142. 
478 Ross, S.T. 2013. Ecology of North American freshwater fishes. University of California Press, $479 \quad$ California.

480 Sogard, S.M. 1997. Size-selective mortality in the juvenile stage of teleost fishes: a review. B. $481 \quad$ Mar. Sci. 60: 1129-1157.

482 Suzuki, K.W., Kasai, A., Nakayama, K., and Tanaka, M. 2005. Differential isotopic enrichment 483 484 485 486 487 488 489 490 491 and half-life among tissues in Japanese temperate bass (Lateolabrax japonicas) juveniles: implications for analyzing migration. Can. J. Fish. Aquat. Sci. 62: 671-678.

Uphoff, C.S., Schoenebeck, C.W., Hoback, W.W., Koupal, K.D., and Pope, K.L. 2013. Degreeday accumulation influences annual variability in growth of age-0 walleye. Fish. Res. 147: 394-398.

Vander Zanden, M.J., Hulshof, M., Ridgway, M.S., and Rasmussen, J.B. 1998. Application of stable isotope techniques to trophic studies of age- 0 smallmouth bass. Tans. Am. Fish. Soc. 127(5): 729-739.

Vander Zanden, M.J., and Rasmussen, J.B. 2001. Variation in 15N and 13C trophic fractionation: implications for aquatic food web studies. Limnol. Oceanogr. 46: 20612066.

494 Vander Zanden, M.J., Clayton, M.K., Moody, E.K., Solomon, C.T., and Weidel, B.C. 2015. 495 496 Stable isotope turnover and half-life in animal tissues: a literature synthesis. PloS ONE

497 Zar, J. H. 2010. Biostatistical analysis, $5^{\text {th }}$ edition. Pearson PLC, Upper Saddle River, New 498 Jersey. 
500 Table 1. Mean isotopic values and standard deviations (SD) measured throughout the diet-switch

501 experiment for age-0 walleye (Sander vitreus) tissues with comparison to brine shrimp diet and

502 artificial diet signatures. Brine samples were measured twice during the course of the study,

503 before the 7-week acclimation period and prior to the experimental diet-switch, to measure

504 consistency of diet signatures.

\begin{tabular}{|c|c|c|c|c|c|c|}
\hline \multirow[b]{2}{*}{ Source } & \multirow[b]{2}{*}{ Tissue } & \multicolumn{3}{|c|}{$\delta^{13} \mathrm{C}$} & \multicolumn{2}{|l|}{$\delta^{15} \mathrm{~N}$} \\
\hline & & $n$ & Mean & $\mathrm{SD}$ & Mean & $\mathrm{SD}$ \\
\hline \multirow[t]{3}{*}{ Experimental diets } & Brine shrimp - Sample 1 & 5 & -20.80 & 0.03 & 12.16 & 0.09 \\
\hline & Brine shrimp - Sample 2 & 5 & -21.01 & 0.04 & 12.34 & 0.08 \\
\hline & Artificial diet & 10 & -21.59 & 0.10 & 8.62 & 0.14 \\
\hline \multirow[t]{2}{*}{ Before diet switch (day -1) } & Dorsal muscle & 4 & -18.66 & 0.15 & 16.12 & 0.16 \\
\hline & Gutted carcass & 4 & -18.86 & 0.25 & 15.52 & 0.10 \\
\hline \multirow[t]{2}{*}{ Initial (day 1) } & Dorsal muscle & 6 & -18.55 & 0.07 & 16.14 & 0.34 \\
\hline & Gutted carcass & 6 & -18.50 & 0.09 & 15.66 & 0.23 \\
\hline \multirow[t]{2}{*}{ Final (day 36) } & Dorsal muscle & 10 & -20.33 & 0.07 & 11.49 & 0.29 \\
\hline & Gutted carcass & 10 & -20.69 & 0.09 & 10.37 & 0.29 \\
\hline
\end{tabular}


506 Table 2. Comparisons of $\Delta \mathrm{AIC}_{\mathrm{c}}$ and $W_{i}$ values among four isotope turnover models. Model A, 507 growth-based with metabolic contribution to turnover; Model B, growth-based with no metabolic 508 contribution; Model C, time-based with metabolic contribution to turnover; Model D, time-based 509 with no metabolic contribution. For all models, $n=56$ and $k=3$.

\begin{tabular}{|c|c|c|c|c|c|c|c|c|}
\hline & \multicolumn{4}{|c|}{$\delta^{13} \mathrm{C}$} & \multicolumn{4}{|c|}{$\delta^{15} \mathrm{~N}$} \\
\hline & \multicolumn{2}{|c|}{ Dorsal muscle } & \multicolumn{2}{|c|}{ Gutted carcass } & \multicolumn{2}{|c|}{ Dorsal muscle } & \multicolumn{2}{|c|}{ Gutted carcass } \\
\hline & $\Delta \mathrm{AIC}_{\mathrm{c}}$ & $W i$ & $\Delta \mathrm{AIC}_{\mathrm{c}}$ & $W i$ & $\Delta \mathrm{AIC}_{\mathrm{c}}$ & $W i$ & $\Delta \mathrm{AIC}_{\mathrm{c}}$ & $W i$ \\
\hline Model A & 9.1 & 0.01 & 13.7 & 0.00 & 6.9 & 0.02 & 7.7 & 0.02 \\
\hline Model B & 3.7 & 0.19 & 5.4 & 0.06 & 2.5 & 0.17 & 9.5 & 0.01 \\
\hline Model C & 2.6 & 0.11 & 6.2 & 0.04 & 2.3 & 0.2 & 2.4 & 0.23 \\
\hline Model D & 0.0 & 0.70 & 0.0 & 0.90 & 0.0 & 0.61 & 0.0 & 0.75 \\
\hline
\end{tabular}


510 Table 3. Parameter estimates (standard error, SE in parentheses) and calculations from the

511 growth- and time based models of $\delta^{13} \mathrm{C}$ and $\delta^{15} \mathrm{~N}$ turnover in age- 0 walleye (Sander vitreus)

512 tissues. Abbreviations and parameter estimates: $c$, turnover constant; $m$, metabolic turnover

513 constant $\left(\right.$ day $\left.^{-1}\right) ; \delta_{\mathrm{f}}$, final asymptotic isotopic value (\%o); and $\Delta$, discrimination between the

514 artificial diet and each tissue (\%). Metabolic turnover constants ( $m$ and $c$ ) that indicate a

515 significant metabolic contribution to tissue turnover at $P<0.05$ are marked with an asterisk $\left(^{*}\right)$.

\begin{tabular}{lllcccc}
\hline Isotope & Tissue & Model & $\mathrm{c}(\mathrm{SE})$ & $\mathrm{m}(\mathrm{SE})$ & $\delta_{\mathrm{f}}(\mathrm{SE})$ & $\Delta(\mathrm{SE})$ \\
\hline$\delta^{15} \mathrm{~N}$ & \multirow{2}{*}{ Dorsal muscle } & Growth-based & $-1.323(0.18)$ & -- & $10.94(0.36)$ & $2.32(0.37)$ \\
& & Time-based & -- & $0.005(0.01)$ & $10.42(0.19)$ & $1.80(0.21)$ \\
& \multirow{2}{*}{ Gutted carcass } & Growth-based & $-1.344(0.22)$ & -- & $10.02(0.29)$ & $1.39(0.31)$ \\
& & Time-based & - & $0.004(0.01)$ & $9.42(0.31)$ & $0.80(0.33)$ \\
$\delta^{13} \mathrm{C}$ & \multirow{2}{*}{ Dorsal muscle } & Growth-based & $-1.524(0.25)^{*}$ & -- & $-20.43(0.11)$ & $1.16(0.11)$ \\
& & Time-based & - & $0.008(0.01)$ & $-20.65(0.11)$ & $0.94(0.12)$ \\
& \multirow{2}{*}{ Gutted carcass } & Growth-based & $-1.788(0.19)^{*}$ & -- & $-20.74(0.08)$ & $0.84(0.08)$ \\
& & -- & $0.023(0.08)^{*}$ & $-20.90(0.08)$ & $0.69(0.08)$ \\
\hline
\end{tabular}


517 Table 4. Isotopic $\left(\delta^{15} \mathrm{~N}\right.$ and $\left.\delta^{13} \mathrm{C}\right)$ turnover rates for age-0 walleye (Sander vitreus) tissues

518 following an experimental diet switch. Both time-based half-life $\left(T_{0.5}\right)$ and number of days to

519 reach $95 \%$ turnover $\left(T_{0.95}\right)$ as well as the proportion of turnover contributed to dilution through

520 growth $\left(P_{g}\right)$ and metabolic activity $\left(P_{m}\right)$ are presented.

\begin{tabular}{llcccc}
\hline Isotope & Tissue & $T_{0.50}$ & $T_{0.95}$ & $P_{g}$ & $P_{m}$ \\
\hline$\delta^{15} \mathrm{~N}$ & Dorsal muscle & 13.0 & 56.3 & 0.91 & 0.09 \\
& Gutted carcass & 13.2 & 56.9 & 0.92 & 0.08 \\
$\delta^{13} \mathrm{C}$ & Dorsal muscle & 12.1 & 52.4 & 0.85 & 0.15 \\
& Gutted carcass & 9.7 & 42.1 & 0.68 & 0.32 \\
\hline
\end{tabular}

521 
522 Table 5. Isotopic $\left(\delta^{15} \mathrm{~N}\right.$ and $\left.\delta^{13} \mathrm{C}\right)$ turnover rates for age-0 walleye (Sander vitreus) tissues

523 following an experimental diet switch. The relative increase in growth necessary for $50 \%\left(G_{0.5}\right)$

524 and $95 \%$ turnover $\left(G_{0.95}\right)$ to the new diet as well as the proportion of turnover contributed to

525 dilution through growth $\left(D_{g}\right)$ and metabolic activity $\left(D_{m}\right)$ are presented.

\begin{tabular}{llcccc}
\hline Isotope & Tissue & $G_{0.50}$ & $G_{0.95}$ & $D_{g}$ & $D_{m}$ \\
\hline$\delta^{15} \mathrm{~N}$ & Dorsal muscle & 1.7 & 9.6 & 0.82 & 0.18 \\
& Gutted carcass & 1.7 & 9.3 & 0.81 & 0.19 \\
$\delta^{13} \mathrm{C}$ & Dorsal muscle & 1.6 & 7.1 & 0.73 & 0.27 \\
& Gutted carcass & 1.5 & 5.3 & 0.64 & 0.36 \\
\hline
\end{tabular}

526

527 


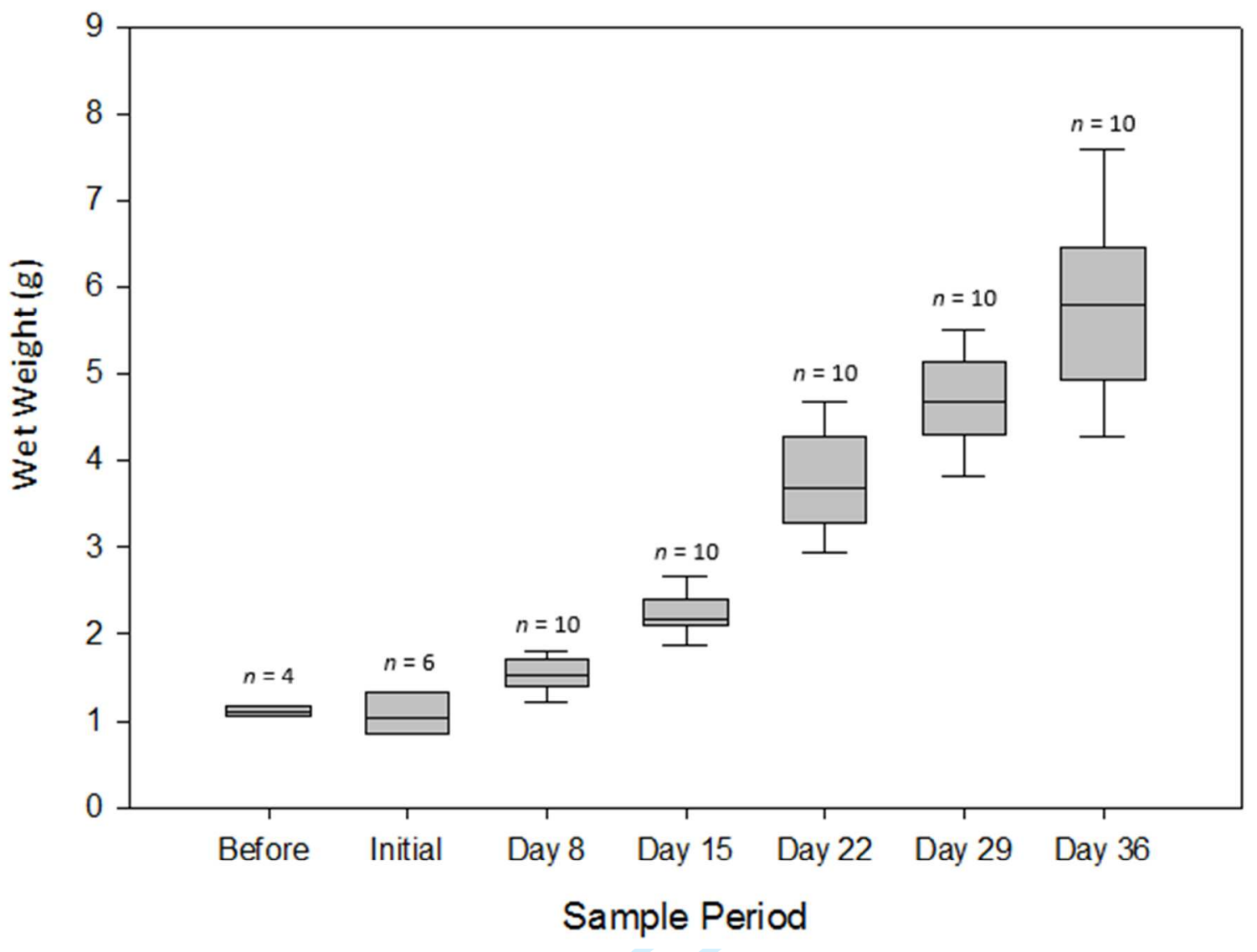

529 Figure 1. Observed wet weight (g) of age-0 walleye (Sander vitreus) before and after 530 experimental diet shift with number of individuals sacrificed each sample period. 
531

532

533

534

535

536

537

538

539

540

541

542

543

544

545

546

547
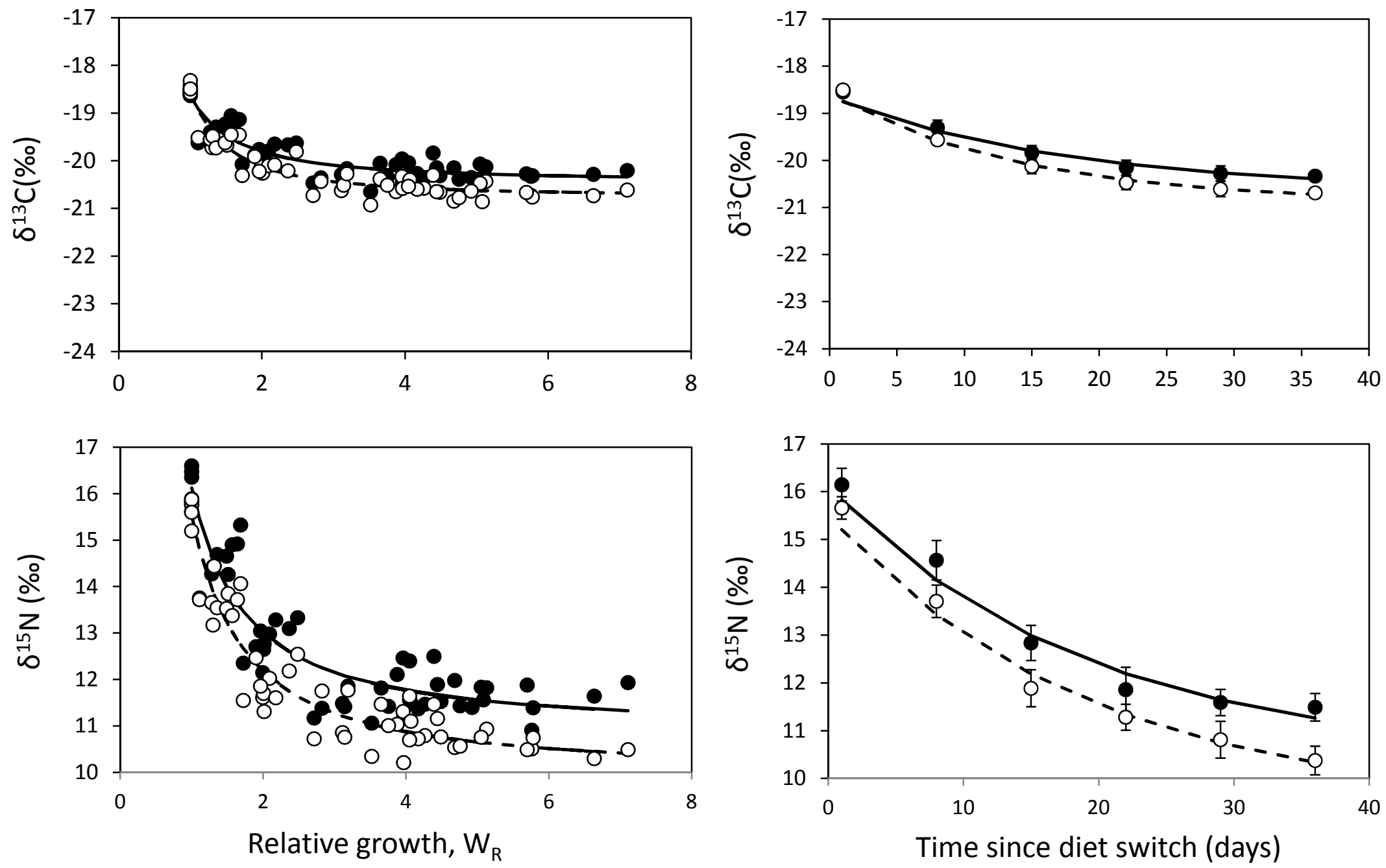

Figure 2. Changes in $\delta^{13} \mathrm{C}$ (top panels) and $\delta^{15} \mathrm{~N}$ (bottom panels) of age-0 walleye (Sander vitreus) tissues as a function of relative growth $\left(\mathrm{W}_{\mathrm{R}}\right.$; left panels) and time (days; right panels) since an experimental diet switch. Data (mean $\left.\pm \mathrm{SD}\right)$ and growth- and timebased model fits are shown for dorsal muscle (solid circles, continuous line) and gutted carcass (open circles, broken line) samples. 


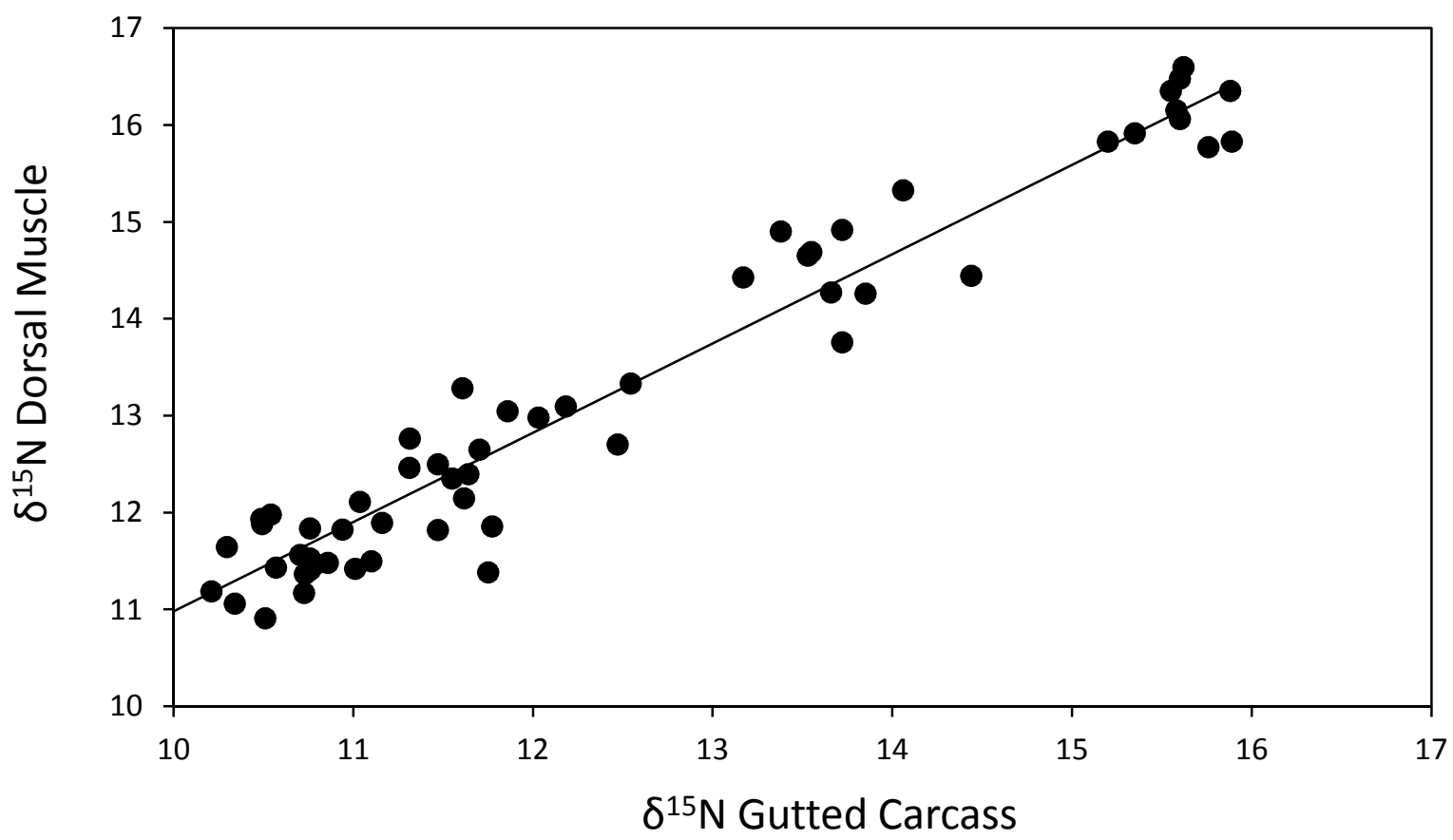

556

557

558

559

560

561

562

563

564

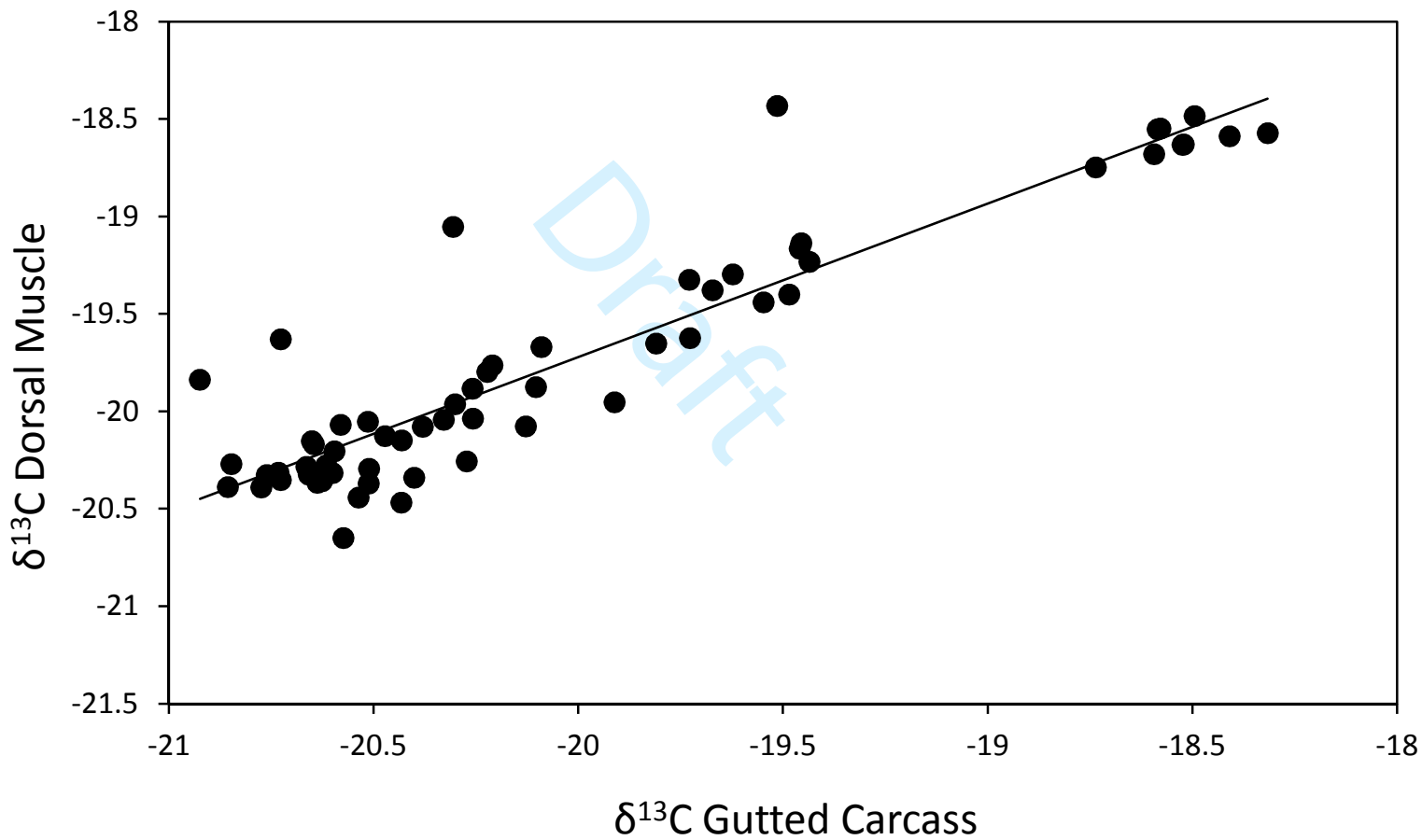

565

566 Figure 3. Relationships between dorsal muscle tissue and gutted carcass sample isotopic values

567 for $\delta^{15} \mathrm{~N}$ (top panel) and $\delta^{13} \mathrm{C}$ (bottom panel) from 60 age-0 walleye (Sander vitreus). 